\title{
CORONAVIRUS AND THE SANITARY CONDITIONS: A REVIEW
}

\author{
Fábio Ribeiro de Oliveira ${ }^{1}$, Edna dos Santos Almeida², Francisco Ramon Alves do \\ Nascimento $^{1}$ \\ ${ }^{1}$ Department of Environmental Engineering, Polytechnic School, Federal University \\ of Bahia, Salvador-Ba, Brazil
}

2 SENAI CIMATEC University Center, Salvador-Ba, Brazil

\begin{abstract}
Studies have showed that precarious sanitary conditions are directly related to the dissemination of the novel coronavirus. The objectives of this work are to characterize the transmission risks of novel coronavirus and to identify prevention and control strategies associated with water, sanitation, hygiene and waste management. The methodology included a review of literature carried out on data basis of Science Direct. After the application of search filters, 10 articles were selected for evaluation and association with the Brazilian context. The results indicated that the social vulnerability associated with the lack of access to adequate conditions of water, sanitation and waste management is one of main problems for the health preservation in times of pandemic.
\end{abstract}

Keywords: SARS-CoV-2; pandemic; water; wastewater; sewage; waste

\section{CORONAVÍRUS E CONDIÇÕES SANITÁRIAS: UMA REVISÃO}

Resumo: Estudos tem mostrado que condições sanitárias precárias estão diretamente relacionadas a disseminação do novo coronavírus. Os objetivos deste trabalho são caracterizar os riscos de transmissão do novo coronavírus e identificar estratégias de prevenção e controle associadas ao saneamento básico. A metodologia contemplou uma revisão da literatura realizada na base de dados do Science Direct. Após a aplicação dos filtros de busca, 10 artigos foram selecionados para avaliação e associação com o contexto brasileiro. Os resultados indicaram que a vulnerabilidade social associada a falta de acesso as condições adequadas de saneamento é um dos principais problemas para a preservação da saúde em tempos de pandemia.

Palavras-chave: SARS-CoV-2; pandemia; água, esgoto, resíduos sólidos. 


\section{INTRODUCTION}

According to COVID-19 pandemic data reported, up to 6 August 2020, by European Centre for Disease Prevention and Control, 18793522 cases and 707715 deaths were confirmed in the world. In Brazil, in the same date, 2859073 cases and 97256 deaths were confirmed [1]. In view of this situation, there is an urgent need of vaccine development and intensification of preventive and control measures for the protection of human life.

Among necessary actions, the sanitation to provide safe water, sewage treatment, waste management and promotion of hygienic conditions are important actions for the protecting human health during COVID-19 pandemic [2]. However, the current global situation has demonstrated the precariousness of the system. Estimates indicated that around $38 \%$ of world population lacked soap and water for washing hands at home [3\}. About $25 \%$ of world population use an unsafe drinking water source due to contamination by faeces [4]. Even if today about 892 million people have defecated in the open [5]

The SARS-CoV-2 transmission can happen by contaminated objects, faecaloral routes and air borne transmission [6]. The COVID-19 contamination possibilities in the urban and rural water cycle, including water and wastewater flow, were studied by Bhowmick et al. [7]. In relation to waste management, recommendations were done by International Solid Waste Association [8].

The objectives of this work were to characterize the transmission risks of novel coronavirus and to identify prevention and control strategies associated with water, sanitation, hygiene and waste management

\section{METHODOLOGY}

This search was carried out in Science Direct database. The following keywords was searched: "Sanitation" and "Covid" and "water or wastewater or waste or sewage" in 2020.

It was applied as inclusion criteria publications with all keywords in the title, abstract or author-specified keywords. Article in duplicity, in case of search for water and wastewater, were considered only once time and the selected articles were correlated with the focus of this work.

Then, the selected articles were evaluated considering: contamination risk, dissemination and infectivity of coronavirus and measures and management actions for minimization of spreading of this virus. The findings were evaluated considering the sanitations conditions in Brazil.

\section{RESULTS AND DISCUSSION}

The Table 1 shows the publications obtained (review articles, research articles and short communications). 
Table 1: Number of articles

\begin{tabular}{|l|c|c|}
\hline \multicolumn{1}{|c|}{ Keywords } & Number of articles & $\begin{array}{c}\text { After inclusion } \\
\text { criteria }\end{array}$ \\
\hline "Sanitation" and "Covid" and "water" & 120 & 12 \\
\hline $\begin{array}{l}\text { "Sanitation" and "Covid" and "wastewater" } \\
\text { or "sewage" }\end{array}$ & 61 & 9 \\
\hline "Sanitation" and "Covid" and "waste" & 51 & 2 \\
\hline Total & 232 & 20 \\
\hline
\end{tabular}

The search in the Science Direct database resulted in 20 articles obtained after applying the exclusion criteria. Of these, 6 articles were in duplicate and 4 were excluded from the sample after evaluation according to the objective of this article.

Then, 10 articles were evaluated. The Table 2 shows the articles selected according the focus of the search and main findings. The main risks of contamination are related to populations in areas with more precarious sanitation, largely associated with lower socioeconomic conditions and high population density, resulting in the difficulty of meeting the Covid-19 prevention protocols. Housing conditions impose limitations on social isolation and the adoption of hygiene procedures recommended by health organizations [9].

Sub-Saharan African populations were cited as an example in which the burden of poor sanitation falls disproportionately on the poor, requiring urgent and innovative pandemic responses in complex circumstances $[10,11]$. This situation also needs to be considered in Brazil, regarding the 4 million families living in households without a bathroom, 35 million living without access to treated water and 100 million without sewerage [12].

Mitigation strategies related to water and effluent management, are mostly associated with urgent political responses. These address issues of social assistance and sanitation management, also depending on research and development of assertive and comprehensive techniques for wastewater monitoring and decontamination.

Related to water and wastewater, several studies [13-18] pointed the presence coronavirus in samples of domestic sewage, hospital wastewater and river or surface water, but not as infectious particles and there is no current evidence that human coronaviruses are transmitted through contaminated drinking-water. This virus has been found in the fecal samples and anal swabs of some patients (due to gastrointestinal illness), but the possibility of fecal-oral (including waterborne) transmission is not clear and proven. 
Table 2: Articles selected and main information

\section{Citation \\ Dissemination risk/infectivity of virus (Transmission risks?)}

Ekumack Dissemination in the most vulnerable populations, who do not have et al [10] access to water, sanitation facility, and food storage.

\begin{tabular}{c|c} 
Street et & $\begin{array}{l}\text { Fecal-oral transmission through direct contact with wastewater, } \\
\text { especially for the most vulnerable communities that practice open }\end{array}$
\end{tabular} defecation or use poor sanitation facilities.

al [11]

Adelodun

et al [13]

Guerrero-

Latorre et al [14]

Heller et

al

La Rosa

et al [16]

Amoah et

al

[17]

Maillard

et al

[18]

Di Maria

et al [19]

$P$

Possibility of contact with contaminated waste. The persistence of the virus on surfaces is influenced by environmental and climatic conditions.

Sharma Changes in the type and amount of waste. Inadequate collection et al [20] practices and poor management systems. Little social cooperation.

Wastewater, especially from treatment sites, may contain Covid-19 socioeconomic status can accentuate the virus's spread.

High values of SARS-CoV-2 loads detected in natural waters from low sanitation region (Quito, Equador), due to direct discharge of sewage water. This fact might pose a risk of infection for the population in

Based in evidence regarding the presence of the virus in stools and sewage, it's were proposed hypothetic routes from faeces to the mouth of a person, such as contact with cleaning water and with surfaces or places where insect vectors are present.

Coronavirus was detected in sewage, but not infectious. In water the virus survival decreases with increasing temperature and oxidants

Untreated wastewater may contain some viable and infective human coronavirus, but the survival could be influenced by factors such as wastewater composition (organic matter), temperature and $\mathrm{pH}$.

Poor hygiene is considered a major factor in the transmission of community-based infections

(1)

\section{Measures and Management actions for}

prevention and control strategies

Assistance to vulnerable families through support from the community, government and international measures. Need for transdisciplinary research and multisectoral policy responses.

Need to establish alternatives for sampling wastewater treatment plants, in order to provide more relevant local monitoring. particles. Local conditions such as high population density and low

The adoption of targeted hygiene measures in homes and daily life offers a way to maximize protection against colonization and infection, at times and places where there is greater risk of transmission.

Temporary stop of waste sorting; instructions for the population to correctly dispose of waste; instructions for the adoption of appropriate personal protective equipment; adequate sanitation conditions.

Ensure safe waste management practices. Automation of waste treatment systems. Building resilient supply chains. Policy responses and proposals. 
The environmental factors that affect the persistence of coronavirus in water is temperature, composition of wastewater in terms of dissolved organic matter and chemicals, acid $\mathrm{pH}$ and competitions with another microorganism. The infectivity of virus declines more rapidly the higher the temperature buy the effect of composition and $\mathrm{pH}$ needs more studies. The structure of coronavirus is an important factor too, and it was reported that this organism can be inactivated significantly faster in water than non-enveloped human enteric viruses [16]. The good news is SARS-CoV-2 appears considered unstable in the environmental conditions and is more susceptible to oxidants, such as chlorine, than non-enveloped viruses.

However, the dissemination of coronavirus in low sanitation countries should be further studied, because the low degree of sewage treatment coverage in this regions, might be a factor of increased risk for COVID-19 pandemic.

For solid waste, the main risk factors are associated with direct contact, mainly by frontline employees responsible for waste collection and processing. It should be noted that the pandemic period resulted in a substantial change in the composition and volume of urban solid waste.

The Brazilian Association of Public Cleaning and Special Waste Companies estimated an increase of 15 to $25 \%$ in the amount of solid household waste generated and a 10 to 20 -fold increase in the generation of hospital waste in health care units in Brazil [21]. Such data, associated with studies of virus persistence on surfaces, show the need for investment in management measures during the pandemic, highlighting practices such as raising public awareness, effective waste management and ensuring workers health protection.

On the other hand, the failure to consider the recycling sector as an essential service in the pandemic period of the new coronavirus, caused countries like the United States and Brazil to stop waste management in some regions [22]. In a broader scenario, including the post-pandemic, there are also points of concern regarding waste: the use of disposable plastic for hygiene reasons; the lack of conscious food consumption; and food waste due to possible restrictions on supply chains [20].

\section{CONCLUSION}

In this document, it was possible to obtain an overview about coronavirus dissemination and aspects related with water, wastewater and solid waste. Further studies are needed to investigate coronavirus persistence in water matrices in relation to climatic and seasonal conditions.

Finally, the Covid-19 pandemic surprised the world population and warned of the precariousness of many sanitation systems, highlighting the need to strengthen technologies appropriate to environment and public policies for the improvement and expansion of sanitation.

\section{REFERENCES}

${ }^{1}$ European Centre for Disease Prevention and Control (ECDC). COVID-19 situation update worldwide, as of 6 August 2020. Available at: <https://www.ecdc.europa.eu/en/geographicaldistribution-2019-ncov-cases>. Accessed on: 06 Aug. 2020. 
${ }^{2}$ World Health Organization (WHO). United Nations Children's Fund (UNICEF). Water, sanitation, hygiene, and waste management for SARS-CoV-2, the virus that causes COVID-19: Interim guidance, 29 July 2020. Geneva: WHO/UNICEF; 2020a. (WHO/COVID19/IPC_WASH/2020.4).

${ }^{3}$ World Health Organization (WHO). United Nations Children's Fund (UNICEF). Joint Monitoring Programme: Hygiene Baselines (pre-COVID-19) - Global Snapshot. WHO/UNICEF. 2020b.

${ }^{4}$ World Health Organization (WHO). Fact sheets: Drinking-water 2019. Available at: $<$ https://www.who.int/news-room/fact-sheets/detail/drinking-water>. Accessed on: 06 Aug. 2020.

5.World Health Organization (WHO). United Nations Children's Fund (UNICEF). Progress on drinking water, sanitation and hygiene: 2017 update and SDG baselines. Geneva: WHO/UNICEF, 2017.

${ }^{6}$ HURAIMEL, K. AL.; ALHOSANI, M.; KUNHABDULLA, S.; STIETIYA, M. H. SARSCoV-2 in the environment: Modes of transmission, early detection and potential role of pollutions. Science of the Total Environment, v. 744, n. 140946, p. 1-10, 2020.

${ }^{7}$ BHOWMICK, G. D.; DHAR, D.; NATH, D.; GHANGREKAR, M. M.; BANERJEE, R.; DAS, S.; CHATTERJEE, J. Coronavirus disease 2019 (COVID-19) outbreak: some serious consequences with urban and rural water cycle. npj Clean Water, v. 3, n. 32, p. 1-8, 2020.

${ }^{8}$ International Solid Waste Association (ISWA). Waste management during the covid-19 pandemic: ISWA's recommendations. ISWA Board, 2020. 12 p.

${ }^{9}$ BEZERRA, A. C. V.; SILVA, C. E. M; SOARES, F. R. G.; SILVA, J. A. M. M. Fatores associados ao comportamento da população durante o isolamento social na pandemia de Covid-19. Ciênc. saúde coletiva, v. 25, 2020.

${ }^{10}$ EKUMAH, Bernard, ARMAH, Frederick Ato, YAWSON, David Oscar, Quansah, Reginald, ESINYIEKUD, Florence, OWUSUE, Samuel, ODOI, Justicequaye, AFITIRIA; Disparate onsite access to water, sanitation, and food storage heighten the risk of COVID-19 spread in Sub-Saharan Africa, Environmental Research, 189, 2020.

11 STREET, Renée, MALEMA, Shirley, MAHLANGENI, Nomfundo, MATHEE, Angela, Wastewater surveillance for Covid-19: An African perspective, Science of The Total Environment, 15, 2020.

12 PIRES, R. R. C. Os efeitos sobre grupos sociais e territórios vulnerabilizados das medidas de enfrentamento à crise sanitária da covid-19: propostas para 0 aperfeiçoamento da ação pública: Nota Técnica Brasília: IPEA; 2020. Available at: http://www.ipea.gov.br/portal/index.php?option=com_alphacontent\&view=alphacontent\&ltemi d=357. Accessed on 04 Aug. 2020.

13 ADELODUN, Bashir, AJIBADE, Fidelis Odedishemi, IBRAHIM, Rahmat Gbemisola, BAKARE Hashim Olalekan, CHOI, Kyung-Sook, Snowballing transmission of COVID-19 (SARS-CoV-2) through wastewater: Any sustainable preventive measures to curtail the scourge in low-income countries? Science of The Total Environment, 10, 2020.

${ }^{14}$ GUERRERO-LATORRE, BALLESTEROS, Laura Isabel, VILLACRÉS-GRANDA, GRANDA Irina M. Genoveva, RÍOS-TOUMA, Blanca, SARS-CoV-2 in river water: Implications in low sanitation countries, Science of The Total Environment, 15, 2020.

${ }^{15}$ HELLER, Léo, MOTA, César R., GRECO, Dirceu B., COVID-19 faecal-oral transmission: Are we asking the right questions? Science of The Total Environment, 10, 2020. 
${ }^{16}$ LA ROSA, Giuseppina, BONADONNA, Lucia, LUCENTINI, Luca, KENMOE, Sebastien SUFFREDINI, Elisabetta, Coronavirus in water environments: Occurrence, persistence and concentration methods - A scoping review, Water Research, 15, 2020.

$17 \mathrm{AMOAH}$, Isaac Dennis, KUMARI, BUX, Sheena Faizal, Coronaviruses in wastewater processes: Source, fate and potential risks, Environment International, 2020.

${ }^{18}$ MAILLARD, Jean-Yves, BLOOMFIELD, Sally F., COURVALIN, Patrice, ESSACK, Sabiha Y., SCOTT, Elizabeth A. Reducing antibiotic prescribing and addressing the global problem of antibiotic resistance by targeted hygiene in the home and everyday life settings: A position paper, American Journal of Infection Controll, 2020.

19 DI MARIA, Francesco, BECCALONI, Eleonora, BONADONNA, Lucia, CINI, Carla, CONFANONIERI, Elisabetta, LA ROSA, Giuseppina, MILENA, Maria Rosaria, TESTAI, Emanuela, SCAINI, Federica, Minimization of spreading of SARS-CoV-2 via household waste produced by subjects affected by COVID-19 or in quarantine, Science of The Total Environment, 2020.

20 SHARMA, Hari Bhakta, VANAPALLI, Kumar Raja, CHEELA, VR Shankar, RANJAN, Ved Prakash, JAGLAN, Amit Kumar, DUBEY, Brajesh, GOEL, Sudha, BHATTACHARYA, Jayanta, Challenges, opportunities, and innovations for effective solid waste management during and post COVID-19 pandemic, Resources, Conservation and Recycling, 2020.

${ }^{21}$ Associação Brasileira de Empresas de Limpeza Pública e Resíduos Especiais (ABRELPE). Recomendações para gestão de resíduos sólidos durante a pandemia de coronavírus (Covid-19). Nota Técnica: 5p., abril, 2020. Available at: < https://abrelpe.org.br/recomendacoes-para-a-gestao-de-residuos-solidos-durante-apandemia-de-coronavirus-covid-19/> Accessed on 04 Aug. 2020.

22 Bureau of International Recycling (BIR). COVID-19: Update by BIR Member National Associations - The world Moves Tentatively Into Reopening Phase Bureau of International Recycling (2020). Available at: <https://bir.org/news-press/news/item/covid-19-update-by-birmember-national-associations-the-world-moves-tentatively-into-reopening-phase> Accessed on 05 Aug. 2020. 